\title{
Police use of deadly force in the State of São Paulo
}

\author{
SAMIRA BUENO ${ }^{1}$ \\ RENATO SÉRGIO DE LIMA ${ }^{2}$ \\ Marco Antônio CARVAlho Teixeira ${ }^{2}$ \\ ${ }^{1}$ Fórum Brasileiro de Segurança Pública (FBSP), SÃo PaUlo - SP, BRAZIL \\ 2 Fundação Getulio Vargas (FGV EAESP) / Escola de Administração Pública de SÃo PaUlo, SÃo PaUlo - SP, BRAZIL
}

\begin{abstract}
The police constitute the main mechanism found by the modern state to guarantee the maintenance of law and order, with the prerogative of regulation of social relations through physical force as a legitimate and constitutive act. While the police represent the authority to intervene when necessary, they may violate citizens' rights when making abusive use of force, especially lethal force. This article presents a descriptive analysis of reports on cases where police used lethal force in the State of São Paulo. The results indicate that, even in the face of a significant reduction in homicides, the use of deadly force by the police increased substantially during the 2000s, disproportionately affecting black people, particularly adolescents and young adults. The research concludes that the police have exceeded the use of deadly force and suggest strengthening the police's internal control to address the problem.
\end{abstract}

Keywords: Public Security. Police. Murder. Deadly Force. Death resulting from police intervention.

\section{Limites do uso da força policial no Estado de São Paulo}

\section{Resumo}

A polícia constitui o principal mecanismo encontrado pelo Estado moderno para garantir a manutenção da lei e da ordem, tendo como prerrogativa a regulação das relações sociais mediante força física como ato legítimo e constitutivo de sua função. Desse modo, ao mesmo tempo que representa a autoridade para intervir quando necessário for, pode constituir um poderoso instrumento de violação de direitos dos cidadãos quando faz uso abusivo da força, em especial a letal. Este artigo apresenta uma análise descritiva das ocorrências de letalidade policial no Estado de São Paulo tendo por base a análise dos boletins de ocorrência dos casos de morte decorrente de intervenção policial. Os resultados indicam que, mesmo diante da redução expressiva dos homicídios dolosos, a letalidade da polícia cresceu substancialmente ao longo dos anos 2000, vitimando desproporcionalmente adolescentes e jovens, pretos e pardos. Concluímos que as polícias paulistas têm se excedido no uso da força letal e sugerimos o fortalecimento do controle interno das corporações para o enfrentamento do problema.

Palavras-chave: Segurança Pública. Polícia. Homicídio. Letalidade. Morte decorrente de intervenção policial.

\section{Límites del uso de la fuerza policial en el estado de São Paulo}

\section{Resumen}

La Policía constituye el principal mecanismo encontrado por el estado moderno para garantizar el mantenimiento de la ley y del orden, teniendo como prerrogativa la regulación de las relaciones sociales a través de la fuerza física como acto legítimo y constitutivo de su función. Así, al mismo tiempo que representa la autoridad para intervenir cuando es necesario, puede constituir un poderoso instrumento de violación de derechos de los ciudadanos cuando hace uso abusivo de la fuerza, en especial, la letal. Este artículo presenta un análisis descriptivo de los casos de letalidad policial en el estado de São Paulo tomando como base el análisis de los reportes de los casos de muerte derivados de la intervención policial. Los resultados indican que, incluso ante la reducción significativo de los homicidios, la letalidad de la policía creció sustancialmente durante los años 2000, victimando desproporcionadamente a adolescentes y jóvenes, negros y pardos. Concluimos que las policías paulistas se han excedido en el uso de la fuerza letal y sugerimos el fortalecimiento del control interno de las corporaciones para enfrentar el problema.

Palabras clave: Seguridad pública. Policía. Homicidio. Letalidad. Muerte derivada de intervención policial. 


\section{INTRODUCTION}

The reduction in the number of homicides in São Paulo has mobilized the academy interest in search of answers to such a sharp and continuous fall for over a decade and a half (FERREIRA, LIMA and BESSA, 2009; MANSO, 2012; NERY, 2016; PERES, VICENTIN, NERY et al., 2011; WILLIS, 2013). Until 1999, however, the state suffered from growing criminality rates, particularly murder, which reached its record when there were 12,000 victims killed in just one year.

The reasons presented for this drastic reduction in lethal violence are subject to controversy and dispute in the academic field and in the public debate. This controversy occurs because a group of scholars and ethnographers claims that the reduction was motivated mainly by the presence and action of the organized crime - predominantly the First Command of the Capital (PCC - Primeiro Comando da Capital) - regulating life in the outskirts of São Paulo (DIAS, 2009; FELTRAN, 2010, 2012; MANSO, 2012; WILLIS, 2013). According to this theory, the PCC would have been able to impose a private monopoly on the exercise of physical violence in prisons and, over time, was able to expand its power to also mediate conflicts on the streets. If previously these spaces were dominated by gangs and disputes among different groups; as the PCC faction gained hegemony, this crime organization began gradually to regulate not only the conflicts but also society's daily conducts according to PCC own codes. Thus, a drug debt that few years ago would inevitably result in a conflict with several deaths came to be brokered by the PCC through "debates" in courts formed by PCC high command in which it would be decided the most appropriate punishment to the debtor. This analytical key highlights the role the organized crime played in social conflicts mediation and management, in detriment of the state, and how it influences the very dynamics of socialization in these territories (DIAS, 2009). Quite controversial, this theory has been strongly rejected by state agents, but it is increasingly gaining adhesion in the academia and the press.

Another strand of researchers has argued that, although organized crime had some impact on reducing murders, it has occurred throughout the state, making it impossible to assert categorically PCC was solely responsible, since it would hardly have enough capillarity, especially in early 2000's. Even though they do not deny PCC might have had some influence on the reduction in the number of murders, they highlight it was due to a combined series of governmental measures adopted since the 2000's as the factors that potentially mostly influenced on this reduction (FERREIRA, LIMA and BESSA, 2009; JUSTUS, KAHN and CERQUEIRA, 2016; LIMA, 2014; NERY, 2016; PERES, VICENTIN, NERY et al., 2011).

Thereby, policies such as the dry law - the closing of bars (BIDERMAN, DE MELLO and SCHNEIDER, 2006; KAHN and ZANETIC, 2005) - gun control and the approval of the Disarmament Statute (PERES, VICENTIN, NERY et al., 2011), demographic changes (MELLO and SCHNEIDER, 2007), improvement on police work force routines by adopting technological tools to provide more agility, compatibilization of Civil and Military Police areas, restructuring the murder investigations department and prioritizing investigations involving recidivism in murder offenders (FBSP, 2015), among others, are factors generally presented as variables that may have contributed to this reduction.

It is very likely the combination of all the indicated variables has favored the murder number reduction, but, although some of these variables might have prevalence in this process, it is hard to determine the participation of each factor. This reduction, however, was not followed by a reduction on the number of deaths resulting from police interventions that, in contrast, increased over the same period. While murders perpetrated by civilians went from 12,475 deaths in 2001 to 4,377 in 2016, indicating there was a $65 \%$ reduction in the number of victims, the number of deaths in consequence of civil and military police interventions went from 605 victims in 2001 to 856 in 2016, an increase of 42\%. This means that the murder rate ranged from 30 per 100,000 inhabitants to 7.9 , and deaths resulting from police interventions jumped from 0.8 to 1.9 per 100,000 inhabitants. 
Graph 1

Rates of murders and death resulting from police intervention - State of São Paulo, 1996-2016

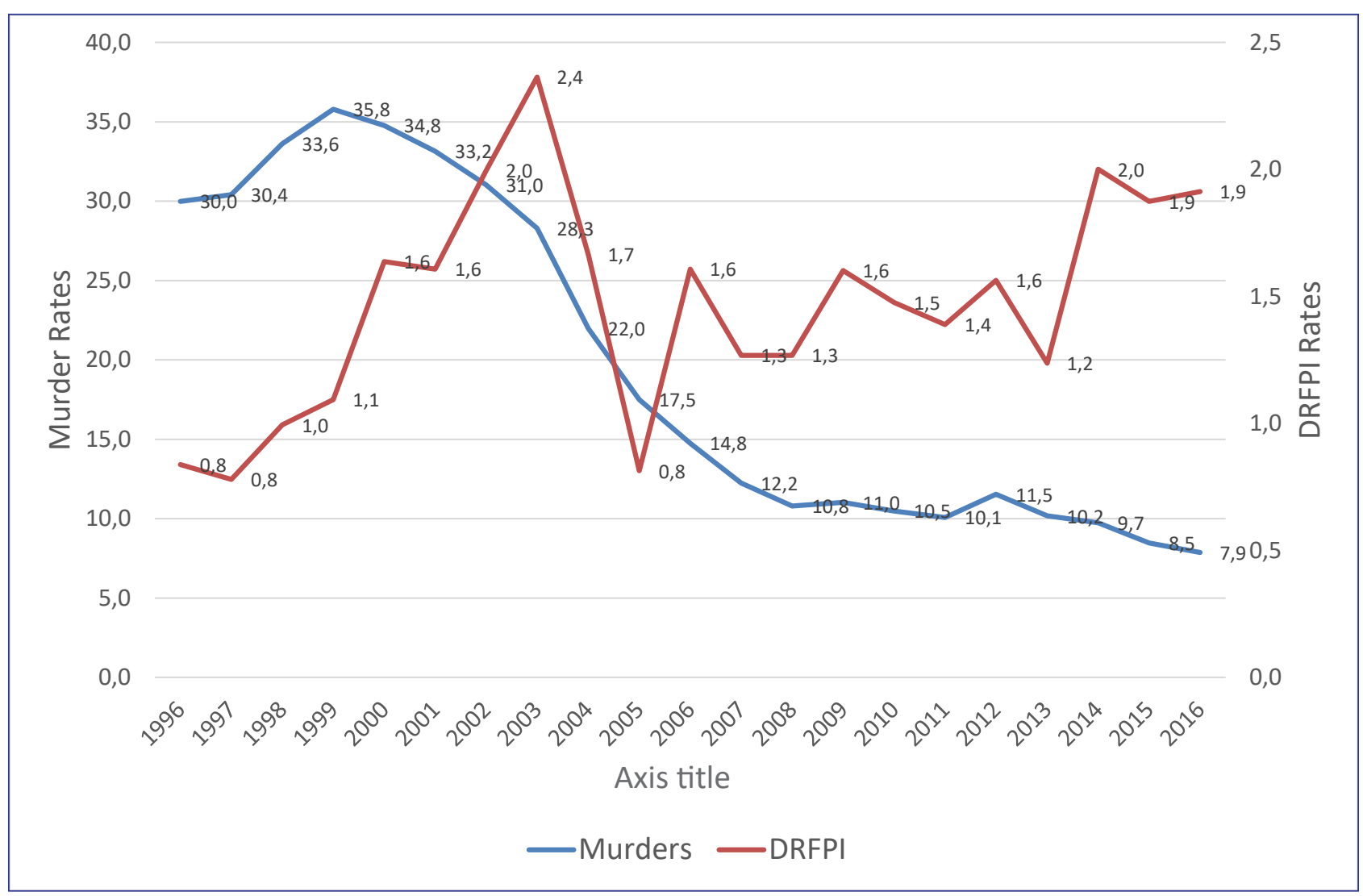

Source: Analysis and Planning Coordinator of the State Secretariat of Public Security.

These results take even more intense outlines when we analyze just the municipalities where the highest numbers of lethality due to police intervention are concentrated, since in them, the reduction of murders was even higher than the state average. Table 1 presents the selection of cities in which are concentrated the highest number in cases of deaths resulting from police intervention (DRFPI), a category equivalent to resistance followed by death in the period before 2013. From the twenty municipalities that presented the highest number of cases in 2016, fifteen coincided with the cities that have the highest number of records in 2001. 
Table 1

Selection of the 15 municipalities of São Paulo with the highest police lethality records in 2001 and 2016, in absolute numbers

\begin{tabular}{l|c|c|c|c|c|c}
\hline \multirow{2}{*}{ Municipalities } & \multicolumn{3}{|c}{ Police letality } & \multicolumn{3}{c}{ Murders } \\
\cline { 2 - 7 } & 2001 & 2016 & $\begin{array}{c}\text { Fluctuation } \\
\text { (\%) }\end{array}$ & 2001 & 2016 & $\begin{array}{c}\text { Fluctuation } \\
\text { (\%) }\end{array}$ \\
\hline State & 605 & 856 & 41,5 & 12.475 & 4.377 & $-64,9$ \\
\hline São Paulo & 343 & 390 & 13,7 & 5.174 & 844 & $-83,7$ \\
\hline Guarulhos & 30 & 34 & 13,3 & 514 & 128 & $-75,1$ \\
\hline Campinas & 28 & 30 & 7,1 & 542 & 115 & $-78,8$ \\
\hline Santo André & 21 & 19 & $-9,5$ & 213 & 38 & $-82,2$ \\
\hline Osasco & 18 & 23 & 27,8 & 330 & 49 & $-85,2$ \\
\hline São Bernardo do Campo & 16 & 21 & 31,3 & 264 & 56 & $-78,8$ \\
\hline Guarujá & 9 & 15 & 66,7 & 157 & 25 & $-84,1$ \\
\hline Carapicuíba & 9 & 6 & $-33,3$ & 195 & 36 & $-81,5$ \\
\hline Santos & 7 & 8 & 14,3 & 103 & 19 & $-81,6$ \\
\hline Mauá & 7 & 5 & $-28,6$ & 184 & 28 & $-84,8$ \\
\hline Diadema & 5 & 13 & 160,0 & 237 & 33 & $-86,1$ \\
\hline São José dos Campos & 5 & 11 & 120,0 & 231 & 74 & $-68,0$ \\
\hline São Vicente & 5 & 9 & 80,0 & 166 & 20 & $-88,0$ \\
\hline Praia Grande & 4 & 12 & 200,0 & 137 & 23 & $-83,2$ \\
\hline Itaquaquecetuba & 13 & 225,0 & 209 & 45 & $-78,5$ \\
\hline Other municipalities & 247 & 263,2 & 3.819 & 2.844 & $-25,5$ \\
\hline
\end{tabular}

Source: Elaborated by the authors based on data from the Analysis and Planning Coordination of São Paulo

State in the Secretariat of Public Security; Resolution SSP-516/00; Diário Oficial do Estado de São Paulo.

São Paulo, Guarulhos and Campinas had, respectively, a reduction of $83.7 \%, 75.1 \%$ and $78.8 \%$ of murders in the period, while the deaths resulting from the police interention had a higher growth. It was 13\% in São Paulo and Guarulhos and 7\% in Campinas. From the fifteen municipalities selected, only three exhibited a reduction in the number of people killed due to police interventions, but all cities had at least a $68 \%$ reduction in murder rates.

Given that the use of lethal force by the police should only be done in exceptional cases, when there is real threat and imminent danger to the physical integrity of the police agents or third parties, and it must obey the principles of legality, necessity, proportionality, moderation and decorum (BRASIL, 2010). In this paper we discuss the paradox between the reduction of homicidal violence in the State of São Paulo and the increase in the number of murders resulting from police intervention through a descriptive analysis of statistics.

The article is divided into five sections, including this introduction. In the next section we present the methodology used; in the third part, we present the theoretical reference and some of the criteria normally used to assess the use of excessive force by the police; in the fourth section we present more detailed information about the police victims profile based on the comparison to the profile of victims of murder in the state. In fifth section we state the conclusion and possible control mechanisms to the use of force by state agents.

\section{METHODOLOGY}

In methodological terms, we analyzed in the universe of incident reports the nomenclatures "death resulting from police intervention" and "murder" registered by the Civil Police between 2013 and 2016 in order to understand the victims profile in both kinds of occurrences. 
The nomenclature "death resulting from police intervention" is a deployment of the category "resistance followed by death" or "act of resistance". The term "act of resistance" ${ }^{1}$ is referenced in the Article 292 of the Criminal Procedural Code (CPP), which authorizes the use of force and the means necessary to defend oneself, others and/or to overcome one's resisting arrest. However the criminal classification adopted in the criminal reports is in article 121 in the Criminal Code, murder, which combined with the article 23 provides for "legal exclusion" when the police makes use of lethal force in state of need, selfdefense and/or in strict compliance with the law (MISSE, GRILLO, TEIXEIRA et al., 2013).

The term "act of resistance" assumed the nomenclature of "resistance followed by death" in the state of São Paulo between the 1970s and 2010. In early 2013, the term was replaced by "death resulting from police intervention", a response of the newly appointed Secretary of Public Security, Fernando Grella to the Resolution no. 8, of December, 20th, 2012, by the Special Secretariat for Human Rights (SSDH) of the Presidency of the Republic, which recommended the suppression of the designations "resistance followed by death" and "acts of resistance" in police records (BUENO, 2014).

To analyze the data related to the police actions victims profile, through the Law on Access to Information (n. 12.527 / 2011), the records of "deaths resulting from police interventions" during the period between 2013 and 2016 were requested. With the list of all victims of these actions in an Excel spreadsheet, the frequency of cases were sorted out by year according to its municipality and police district of the Civil Police/Military Police Company in which the death occurred, in addition to the victim's information, such as gender and age and race/skin color. Based on the crime report exact localization, including the latitude and longitude report data, maps were generated presenting the geographic distribution of murders per year.

\section{Police and the use of force in democratic societies}

In all countries of the world, the police have been the main agent of state force. Monjardet (2002) states that the police are the institution responsible for owning, mobilizing and regulating the use of force in internal social relations, whereas Bittner defines it as a "[...] mechanism of non-negotiable coercive force distribution, employed according to the precepts of an intuitive understanding of what the situation demands"(BITTNER, 2003, p. 138). For Bayley (1994), modern police should be defined as a group of people who are authorized by a group of citizens to regulate interpersonal relations in a given territory through the use of physical force. From this perspective, it should have two essential elements to the fulfillment of its function: the necessary authority to intervene when it is imperative to restore public order and the symbolism of justice that it represents in its investigation and the elucidation of crimes.

In any case, regardless the police definition of choice, the defining feature of all police organizations is, par excellence, the potential of using physical force as a social conflicts management mechanism. And, although Bittner's (2003) understanding seems to be somewhat subjective, in practice, that is exactly what is in police discretion. After all, it is up to the police officer, the street-level bureaucrat (LIPSKY, 2010), to decide on which means, instruments and intensity of force will be expended to control any given situation.

In fact, the use of force by police officers does not only happen during confrontation or arrest situations, but it is also an expected presupposition: it is the potential of police using force that causes a citizen to turn to the police to solve a problem, a fundamental institution for any democracy (MUNIZ, PROENÇA JUNIOR and DINIZ, 1999). Accordingly, the presence of a uniformed police officer on the street is, by itself, a display of the state force, albeit symbolic, since the threat of force that this officer is imbued informs those around the officer the limits on what can and cannot be done. The police act as the guarantee of the public order.

However, the position police occupy in society also puts them in a constant ambiguity zone because, while ensuring rights and protection, they are responsible for repression and are also often feared. In view of this, as might be expected, the police officers who work on the street must permanently deal with this tension and ambiguity in the development of their duties, and the discretion that the legal system confers to the officers cannot be misused as arbitrariness (BRETAS and PONCIONI, 1999).

If the nature of the police mandate lies precisely in the potential to use coercive power by physical force in a legitimate and legal manner (MUNIZ, PROENÇA JUNIOR and DINIZ, 1999), it is important to emphasize that the use of lethal force is foreseen

\footnotetext{
${ }^{1}$ Sergio Verani (1996 apud MISSE, GRILLO, TEIXEIRA et al., 2013) states that the act of resistance was officially created in 1969 by the Guanabara State Police Superintendence through Service Order No. 803.
} 
as a prerogative of the police mandate, provided it obeys the parameters of necessity, legality, proportionality, moderation and convenience and that it is used to protect the lives of the police and third parties.

One of the biggest challenges faced in police force studies is to differentiate between the legal use of force - which, at its most extreme level, can result in the death of a third party - from abuse. Even international regulations ${ }^{2}$ ruling over the use of force by police, such as the UN document "Basic Principles of the Use of Force and Firearms by Law Enforcement Officials", do not accurately differentiate between the use of force and the use of force and violence. The fourth principle of the document, for example, states that law enforcement officials must use non-violent means before resorting to the use of force and firearms. As the wording is vague and does not define objective criteria, it creates loopholes to alternative interpretation in disregard of "[...] verbalization, negotiation, or unarmed defensive techniques as legitimate (not violent) ways of using force in conflict resolution" (INSTITUTO SOU DA PAZ, 2013, p. 243).

Indeed, legislation regulating the use of force by state agents is quite recent in Brazil. The first normative on the theme was only published in 2010 (BRASIL, 2010) and refers to the use of force by public security agents of the Federal Police, Federal Highway Patrol, Federal Railway Patrol and National Police Force. For states and municipalities, this ordinance has the power only to advice, binding the transfer of resources to compliance to the defined guidelines ${ }^{3}$ (BUENO, 2014). However, since its implementation the Ministry of Justice has not stated a monitoring system regarding this theme for the Federation units, which precludes the conditionings to transfer of financial resources to the compliance with the recommended guidelines.

In 2014, law 13.060 was approved, which regulates the use of lower potential offensive tools by public security agents. The law restricts the use of firearms in situations of fleeing, unarmed or without imminent potential risk of death or injury to law enforcement officials or third parties; and against a vehicle that violates police blockade on public roads, except when the act represents an imminent potential risk of death or injury to public security agents or third parties. Complementarily, the law also requires that public security agents training courses include in its program content the use of non-lethal instruments. Despite the legal framework available to assess the necessity, legality and proportionality in the use of force, it is difficult to differentiate legitimate use of lethal force from abuse.

Skolnick and Fyfe (1993) argue that the most critical point in determining whether or not violence was disproportionally used by a police officer is precisely the progressive increase on the use of force: how much force and what instruments a police officer should use in each situation? How is it possible to differentiate the legitimate use of force from an episode in which there was abuse or any kind of illegality?

Internationally the literature has highlighted three criteria for measuring whether the police are using excessively lethal force, from which we highlight: 1 ) the rate of civilians killed by the police in relation to the total number of murders; 2 ) the ratio between dead civilians and dead police officers; 3 ) the ratio between injured civilians and civilians killed by the police, called the lethality index (BUENO, 2014; CHEVIGNY, 1995; COSTA, 2004; LOCHE, 2010).

The first criterion aims to contextualize the police force lethality in the scenario of urban violence altogether (COSTA, 2004). According to this first criterion, a territory that might apparently have many cases of lethal force use by the police, but this number is unrepresentative when compared to the total number of murders. Or the number of deaths due to police interventions may appear to be low but correspond to a high percentage of murders, indicating that there is excessive use of

\footnotetext{
${ }^{2}$ International principles governing the use of force and firearm are expressed in the following documents: 1) Code of Conduct for Law Enforcement Officials, adopted by the United Nations General Assembly in its Resolution 34/169 of December, 17th, 1979; 2) Basic Principles on the Use of Force and Firearms by Law Enforcement Officials, adopted at the 18th United Nations Congress on Crime Prevention and Treatment of Offenders, held in Havana, Cuba, from August, 27th to September, 7th, 1999; 3) Guiding Principles for the Effective Enforcement of the Code of Conduct for Law Enforcement Officials, adopted by the United Nations Economic and Social Council in its resolution 1989/61 of May,24th, 1989; and 4) Convention Against Torture and Other Cruel, Inhuman or Degrading Treatment or Punishment, adopted by the UN General Assembly at its XL Session, held in New York on December, 10th, 1984, and promulgated by Decree No. 40 of February,15th, 1991. As the documents were approved during the United Nations Assembly, the binding of member states is automatic and are now part of international human rights protection regulations (PINC, 2011).

${ }^{3}$ The document consists of 25 guidelines, which include: "[...] the use of force by law enforcement officers shall obey the principles of legality, necessity, proportionality, moderation and convenience; [...] law enforcement officers shall not fire firearms at persons, except in cases of self- or third-party selfdefense against imminent danger of death or serious injury; [...] It is not legitimate to use firearms against a fugitive person who is unarmed or who, even in possession of any kind of weapon, does not pose an immediate risk of death or serious injury to law enforcement officials or third parties; [...] it is not legitimate to use firearms against a vehicle that violates police blockade on public roads, unless the act poses an immediate risk of death or serious injury to public security agents or third parties ... ] " (BRASIL, 2010, p.3)
} 
lethal force by local police (BUENO, 2014). In the state of São Paulo, police lethality corresponds to $25 \%$ of all homicides, the highest coefficient in the country according to data assessed by the Brazilian Public Security Yearbook (FBSP, 2018).

The second criterion states that there must be some proportionality in the number of deaths of civilians and police officers. By this logic, when the number of deaths resulting from police intervention is much higher than the number of deaths of police officers, the police are probably abusing the use of lethal force. Loche (2010) states that there is normative difficulty in establishing what would be an acceptable standard on lethal force use by the police. However, the Federal Bureau of Investigation (FBI) works with the ratio of 12 civilians killed to each police officer killed and Chevigny (1995), claims it should be 10 to 1 (BUENO, 2014). This index seems questionable to measure the use of lethal force by police in Brazil because it presumes that all, in both cases, civilians killed by the police and dead police officers would have occurred in confrontational situations, and from this some proportionality could be drawn. However, studies made in Brazil indicate that about $70 \%$ of murdered Brazilian police officers die when they were off duty (FBSP, 2017), usually at the so-called "bicos", it is a Brazilian slang that means "beak" and refers to a second part-time job, it may be occasional or permanent, usually with no benefits or minimum entitlements (FERNANDES, 1973).

The third criterion states that, under democratic normality conditions, there would be more people injured than killed in police actions. This is a very difficult criterion to be evaluated in Brazilian national context, either due to the lack of statistics or to the particular characteristics of those episodes, which are not recurrently recorded by the police authorities.

Another possible criterion indicated here to measure the use of lethal police force in Brazil concerns the proportion of civilians killed in relation to the number of arrests and arrests in flagrante delict. This criterion might not be the most appropriate for other realities, but as in Brazil and specifically in São Paulo most arrests occur in the act (flagrante delict), many of which, after police interventions, assessing how many deaths occur in relation to the number of arrests and underage apprehensions in flagrante delict might constitute a relevant mechanism of measurement.

Graph 2 shows the rate of death by PMESP (Polícia Militar do Estado de São Paulo - São Paulo Military Police Force) per 1,000 adult arrests and 1,000 underage apprehensions in the state of São Paulo between 2013 and 2016. Data indicate that adolescents are more victimized than adults in interactions with police officers, reinforcing the age component as a strong explanatory variable in police violence, which will be discussed in the next section.

\section{Graph 2}

PMESP death rate per 1,000 arrests and apprehensions by age group - São Paulo State, 2013 to 2016

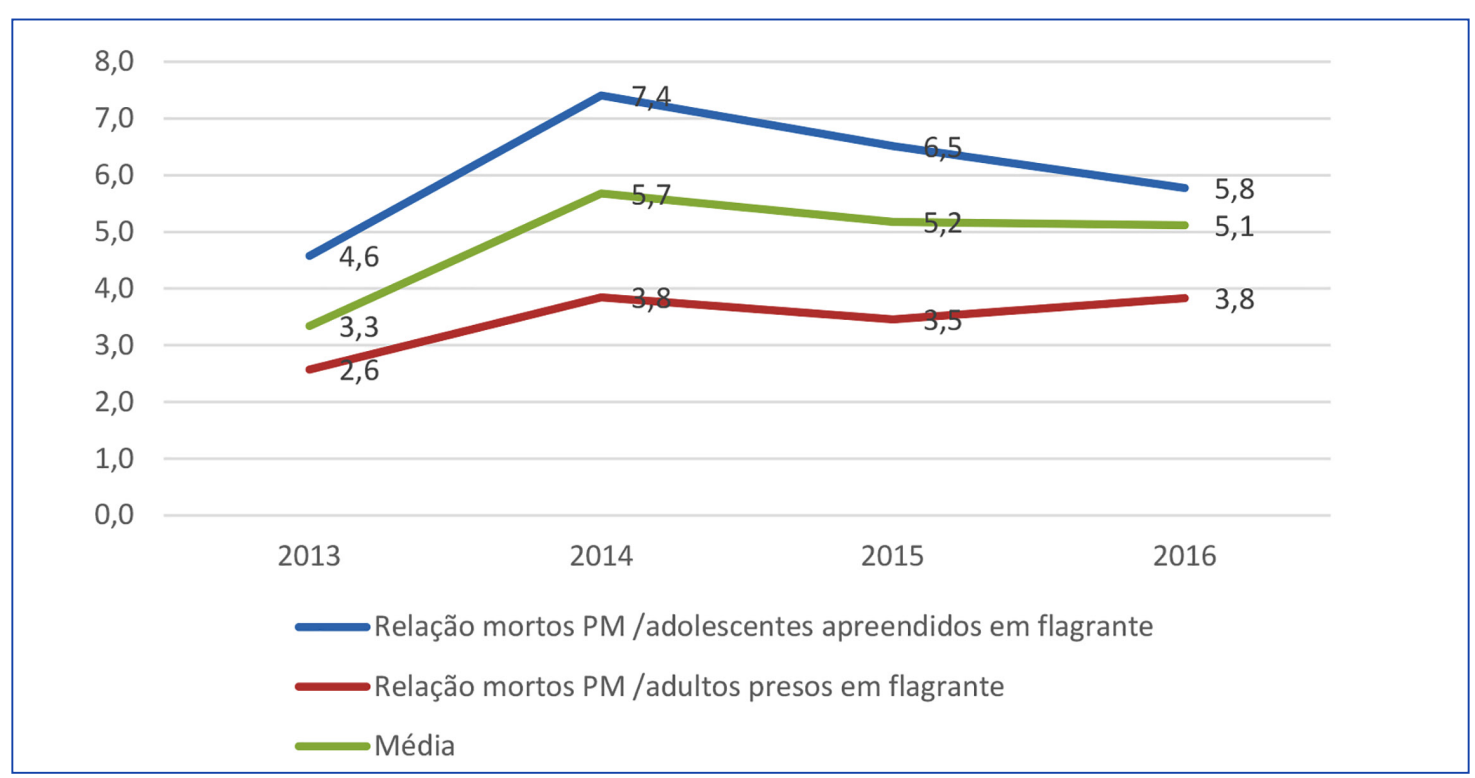

Source: Elaborated by the authors based on CAP / SSP data. 


\section{RESULTS}

Figure 1 shows the spatial distribution of deaths resulting from police interventions based on latitude and longitude data in the 2016 police reports. The data indicate that most of São Paulo municipalities did not present any incident and that 20 municipalities concentrated around $70 \%$ of all deaths resulting from police interventions.

Figure 1

Territorial distribution of deaths resulting from police intervention, absolute numbers - São Paulo, 2016

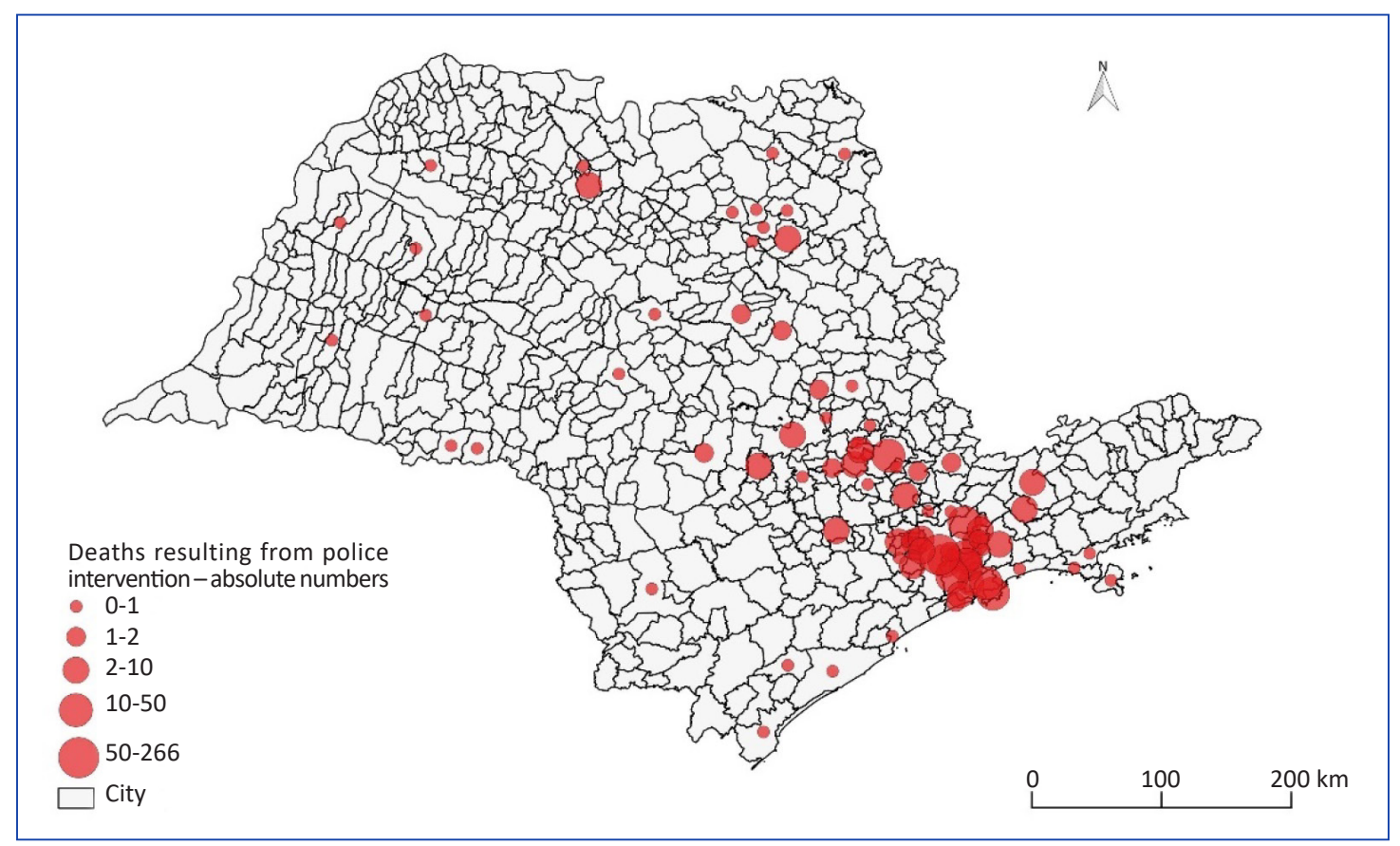

Source: Elaborated by the authors based on CAP / SSP data.

There is a concentration of lethality incidents in São Paulo capital, Metropolitan Region of São Paulo, Baixada Santista (Santos city and nearby localities) and some regions in the countryside of the state, such as Ribeirão Preto and São José dos Campos. An explanatory hypothesis is the presence of more intensely organized crime in these territories, which might trigger more conflicts and, consequently, more cases resulting in deaths involving police actions. These cities also concentrate the largest population and are the richest cities in the state, but not necessarily the ones with the highest violence rates.

Figure 2 shows the rates of DRFIP in the state capital from 2013 to 2016. The first point to be highlighted is lethality escalation in the city of São Paulo over time. Another extremely worrying factor in the analysis by police district is that the DRFIP rate in police districts in the eastern or northern suburbs of São Paulo is higher than 10 per group of 100,000 inhabitants, that is higher than the average murder rate in the state of São Paulo, which was 8.9 in 2016. A study by Lester (1996) states that the environment where the individual police officer operates and the perception that illegalities could be committed without any real consequences on the officers' career are important factors that will influence the police officers' decision whether or not to use force, especially lethal force. Working in areas that are considered to be among the most violent and in which socioeconomic indicators are worse may influence the agents perception of the risk to which they are undergoing, encouraging the police agents to make use of lethal force. 
Figure 2

Death resulting from police intervention - Rate by police district in the city of São Paulo, 2013 to 2016

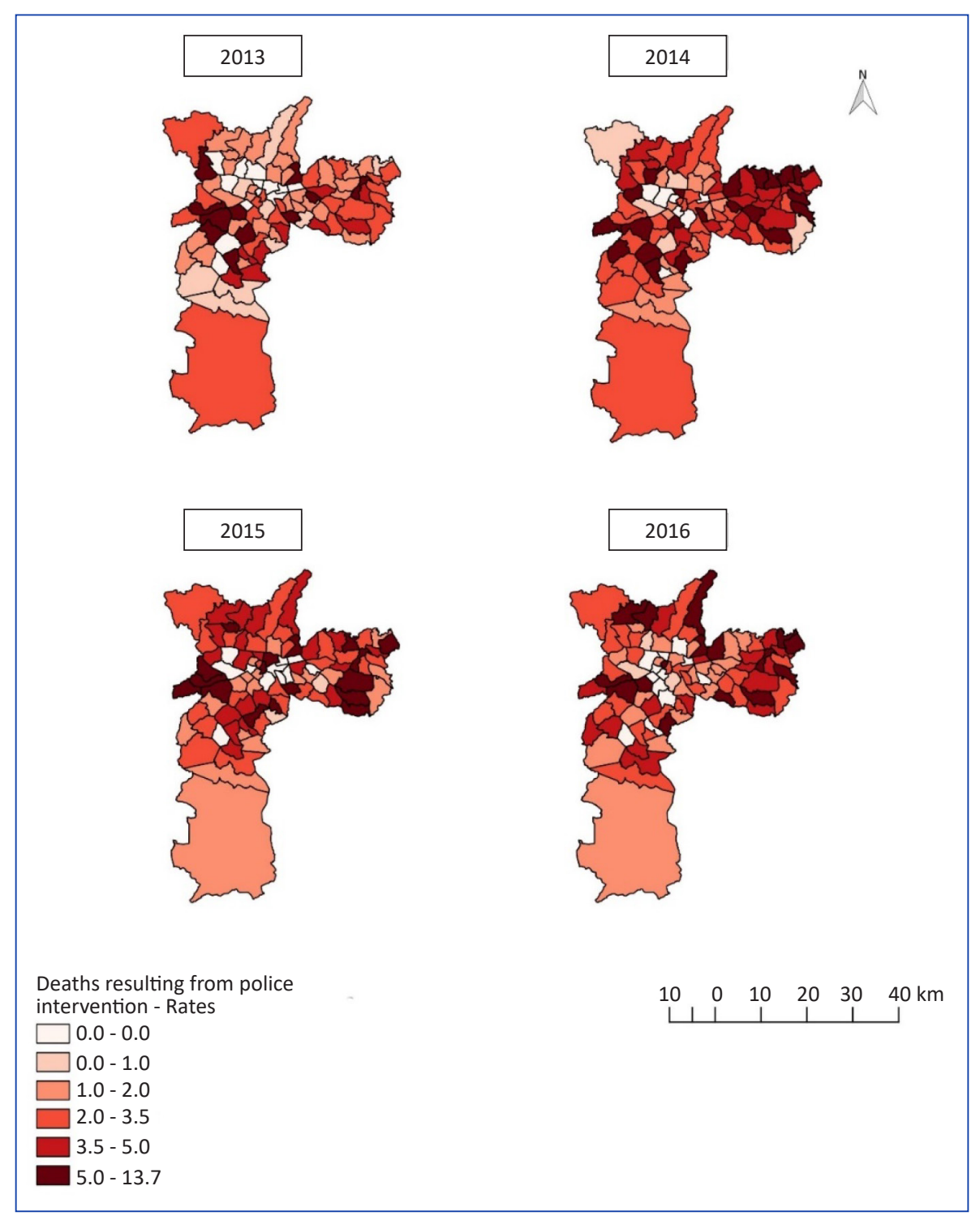

Source: Elaborated by the authors based on CAP / SSP data. Population estimate by SD produced by Marcelo Batista Nery (2016) with data from Fundação SEADE.

Yet, the police discourse points out that a considerable part of the ostensible policing work consists in suppressing crime by trying to control the drug market and to fight against organized crime, strategies that would be focused on peripheral neighborhoods with high social disorganization rates. From this perspective it would be natural that police lethality would happen prevalently in these peripheral regions, while in more central regions of the city it would not occur. Also derived from this point of view, the visibility generated by actions recognized as positive and/or legitimate in the fight against crime could influence the population acceptance of the levels of violence used by police, making more palatable the police tactics that would not be seen at the same way in middle-class neighborhoods. This in itself would function as a mechanism for restricting and controlling the use of police force in certain territories (BRUNSON and MILLER, 2006).

The evolution analysis of the cases when considering São Paulo Metropolitan Region also indicates the escalation on police lethality in recent years (Figure 3). Cities such as Juquitiba, Guararema and Santa Isabel start to exhibit high rates of police lethality, as well as the capital and the cities traditionally considered to be more violent, including Guarulhos, Carapicuíba and Osasco. 
Figure 3

Rate of deaths resulting from police intervention by municipality of the São Paulo Metropolitan Region, 2013 to 2016

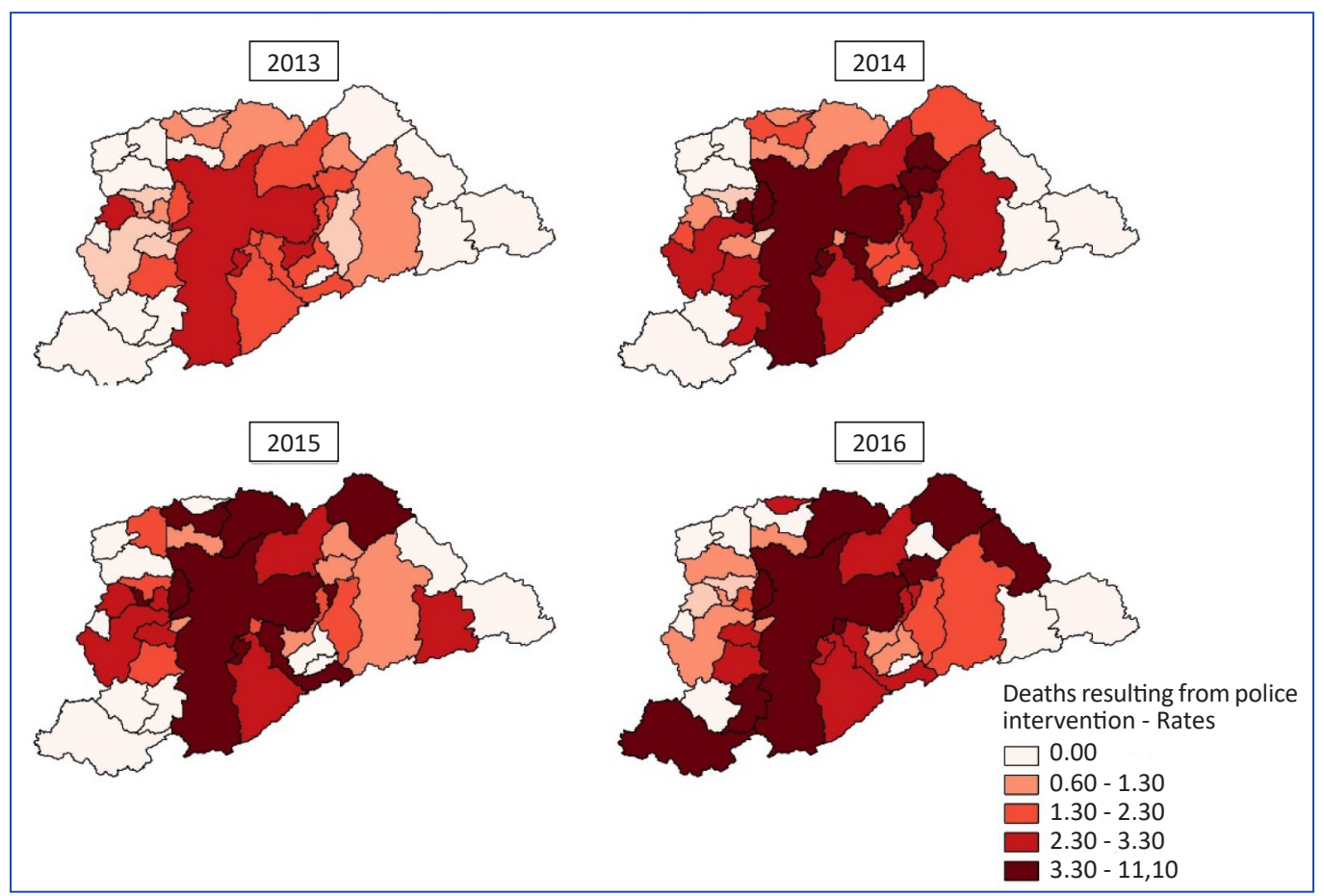

Source: Elaborated by the authors based on CAP / SSP data. Population estimate by SD produced by Marcelo Batista Nery (2016) with data from Fundação SEADE.

In the same way as the explanations given by the police officers, Kania and Mackey (1977) draw a relation between the number of deaths caused by police actions in 50 US states to the risk the police have of being murdered, it means that police violence would be a response to the violence levels in the territory, and this would implicate in areas without action resulting in death. Fyfe (1982) put to the test some of Kania and Mackey's hypotheses in 2,746 episodes in which US police officers used firearm but it did not necessarily result in death. The author found a correlation between police violence and local crime rates and that it could pose threat to police officers.

The prevalence of men amongst the lethal violence victims is a phenomenon that has been described in several studies, but in cases of police lethality it seems to assume an even greater proportion. Cano (1997), in a study based on records of "resistance followed by death" in the 1990s in Rio de Janeiro, found that $94 \%$ of the victims were male. In São Paulo, the data collected indicate even higher proportions: more than $99 \%$ of police victims were men (Table 2).

Table 2

Victims according to gender, murders and death resulting from police intervention - São Paulo, 2014 to 2016

\begin{tabular}{l|c|c|c|c|c|c}
\hline \multirow{2}{*}{$\begin{array}{c}\text { Victims according } \\
\text { to gender }\end{array}$} & \multicolumn{3}{|c|}{ Murders } & \multicolumn{3}{c}{ DRFPI } \\
\cline { 2 - 7 } Male & 2014 & 2015 & 2016 & 2014 & 2015 & 2016 \\
\hline Female & 85,3 & 87 & 85,2 & 99,7 & 99,3 & 99,6 \\
\hline Non specified & 12,3 & 13 & 12,9 & 0,0 & 0,4 & 0,2 \\
\hline
\end{tabular}

Source: Elaborated by the authors based on CAP / SSP data. 
The research developed by Brunson and Miller (2006) indicates that when police approaches are violent, the citizens' resistance to obeying police orders increases. The authors also suggest that African descent people have a higher rate of negative interactions with the police, showing that the correlation between race and behavior of the person who is object of police action is influenced by how the corporation interacts with citizens in more socioeconomically vulnerable territories. Similarly, research released by Datafolha revealed that African descent people and mulattos are more afraid of being victims of police violence (MENA, 2017) while white people are more inclined to accept the saying "the only good thief is a dead one". The Trust in Justice Index presented by the Getúlio Vargas Foundation of São Paulo (FGV-SP) reveals that white people have a higher rate of satisfaction regarding the police than African descent people (FÓRUM BRASILEIRO DE SEGURANÇA PÚBLICA, 2015). Kappeler, Sluder and Alpert (1994) argue that because they are more victimized and have proportionally a higher number of negative interactions with the police, minorities would tend to be more critical of police activity.

The data compiled here indicate that 62.1\% of victims of police actions in São Paulo between 2013 and 2016 were African descent and 33.9\% white, as shown below in Graph 3.

\section{Graph 3}

Fatal Victims of Police Interventions in the State of São Paulo, by race/skin color 2013-2016

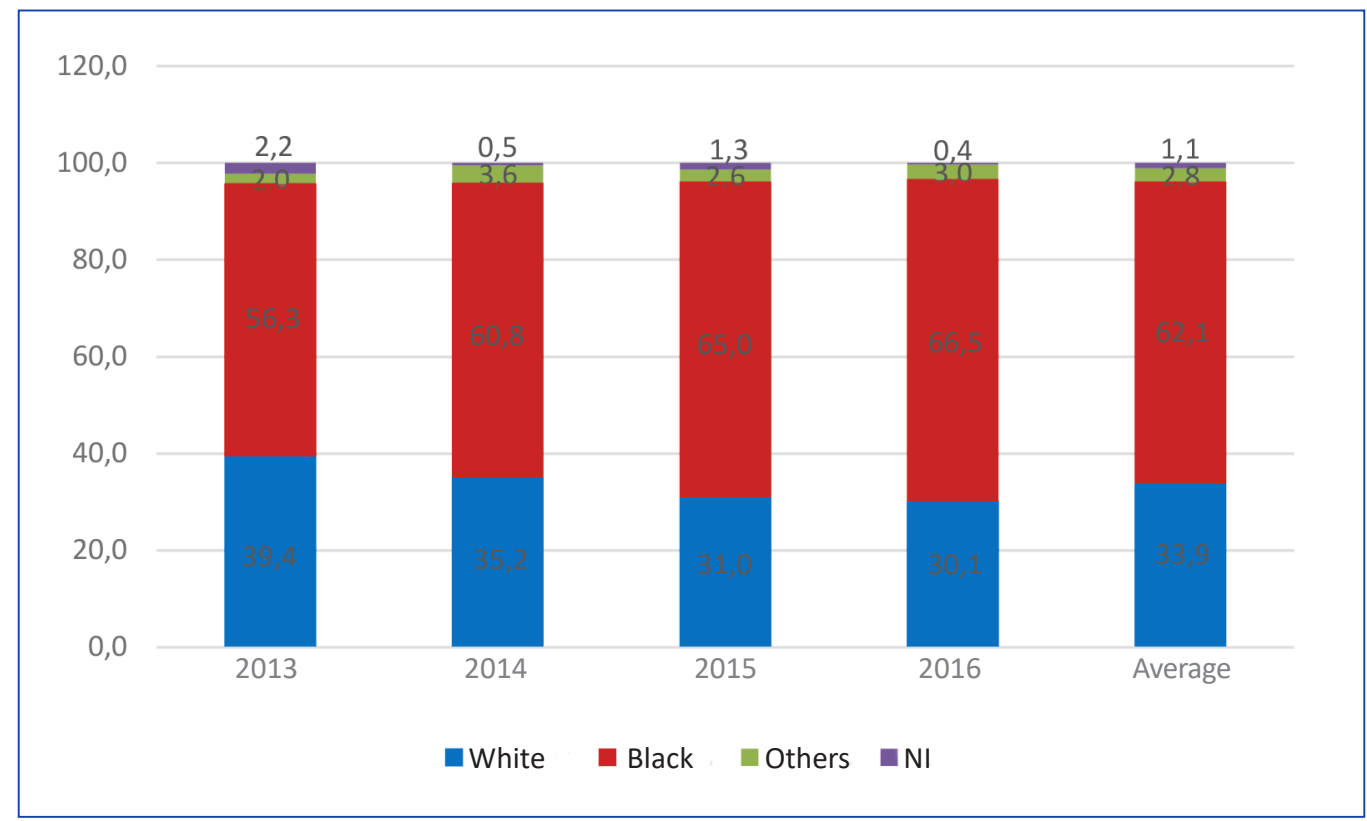

Source: Elaborated by the authors based on CAP / SSP data.

There is an inversely proportional correlation between the population and the victims of police intervention resulting in death: while white people represent $63.1 \%$ of the São Paulo population, only $30 \%$ of those is the victim of police action; while African descent people, who represent $36.9 \%$ of the total state population, are $66.5 \%$ of the victims. 


\section{Graph 4}

Proportion of African descent and White people in the total Brazilian population; among homicide victims and among victims of deaths from police interventions - São Paulo, 2016

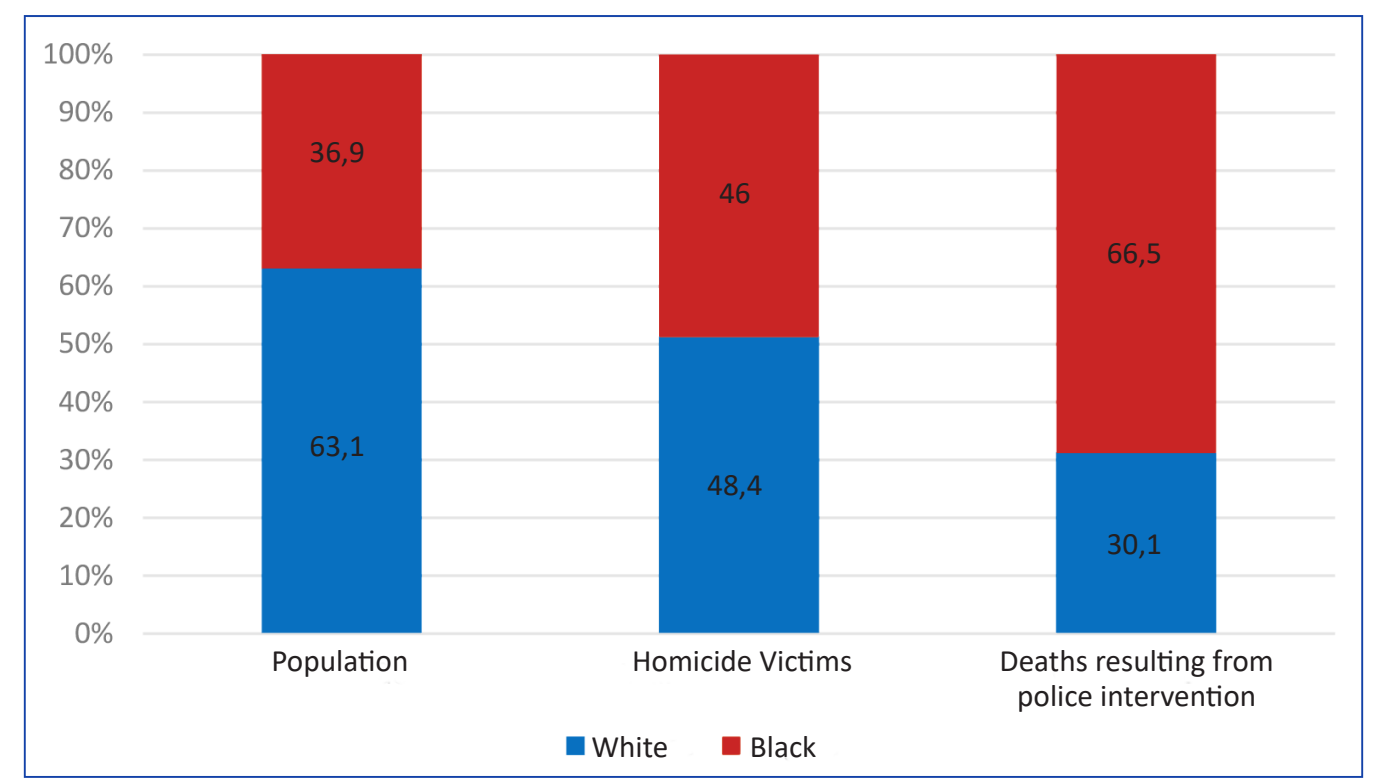

Source: Elaborated by the authors based on CAP / SSP data.

Brunson and Miller (2006), in surveys conducted in the US, indicate that African descent people are more dissatisfied and distrustful of police work than other ethnic-racial groups, which would be directly related to individual experiences with the police. Studies also indicate that the corporation acts differently in neighborhoods of higher socioeconomic vulnerability or city outskirts compared to middle-class neighborhoods (KLINGER, 1997), which also supports the concentration of lethality incidents by police action observed in Brazilian researchs (CANO, 1997; SINHORETTO, BATITUCCI, MOTA et al., 2014) ${ }^{4}$.

Yet in the correlation between territory and race, Reinach, Rondinone and Moya-Latorre (2017) ${ }^{5}$ recently presented, at the Massachusetts Institute of Technology (MIT), data on police lethality in the city of São Paulo, seeking explanations on the pattern of spatial distribution of occurrences and their relation to socioeconomic indicators. The study shows that the districts in the state capital expanded center - which have fewer cases of DRFPI - also concentrate $80 \%$ of the white population. On the outskirts of the city, in districts far from the city center, where police interventions results in more deaths, is also where $60 \%$ of the African descent population reside. Another element brought by the authors presents the concentration of young population by region, indicating that it concentrates mainly in the peripheral regions of the city, while the majority of the expanded center residents is over 25 years old.

Reinforcing this scenario of inequality, Reinach, Rondinone and Moya-Latorre (2017) indicate that in the central area average citizen income can be up to twenty times higher than the income in the outskirts, and that the farther from the center, the sharper this is difference in the average income.

Data indicate that African descent people are overrepresented among police victims, which can be seen in Graph 5 that shows mortality rates in result of police interventions by race/skin color. The mortality rate among African descent people is 3.5 times higher than the mortality rate among non- African descent.

\footnotetext{
${ }^{4}$ Recently the Rota Commander made a similar statement, creating great controversy ADORNO, L. Abordagem nos Jardins tem de ser diferente da periferia, diz novo comandante da Rota. UOL, São Paulo, Aug. 24, 2017. Available at: <https://noticias.uol.com.br/cotidiano/ultimasnoticias/2017/08/24/abordagemno-jardins-e-na-periferia-tem-de-ser-diferente-diz-novo-comandante-da-rota.html>. Accessed on: Feb. 16, 2018.

${ }^{5}$ The study was the result of the work developed for the Geographic Information Systems course at MIT by Sofia Reinach, to whom we thank for submitting the data. The article has not yet been published.
} 


\section{Graph 5}

Mortality rate from police interventions by race/skin color

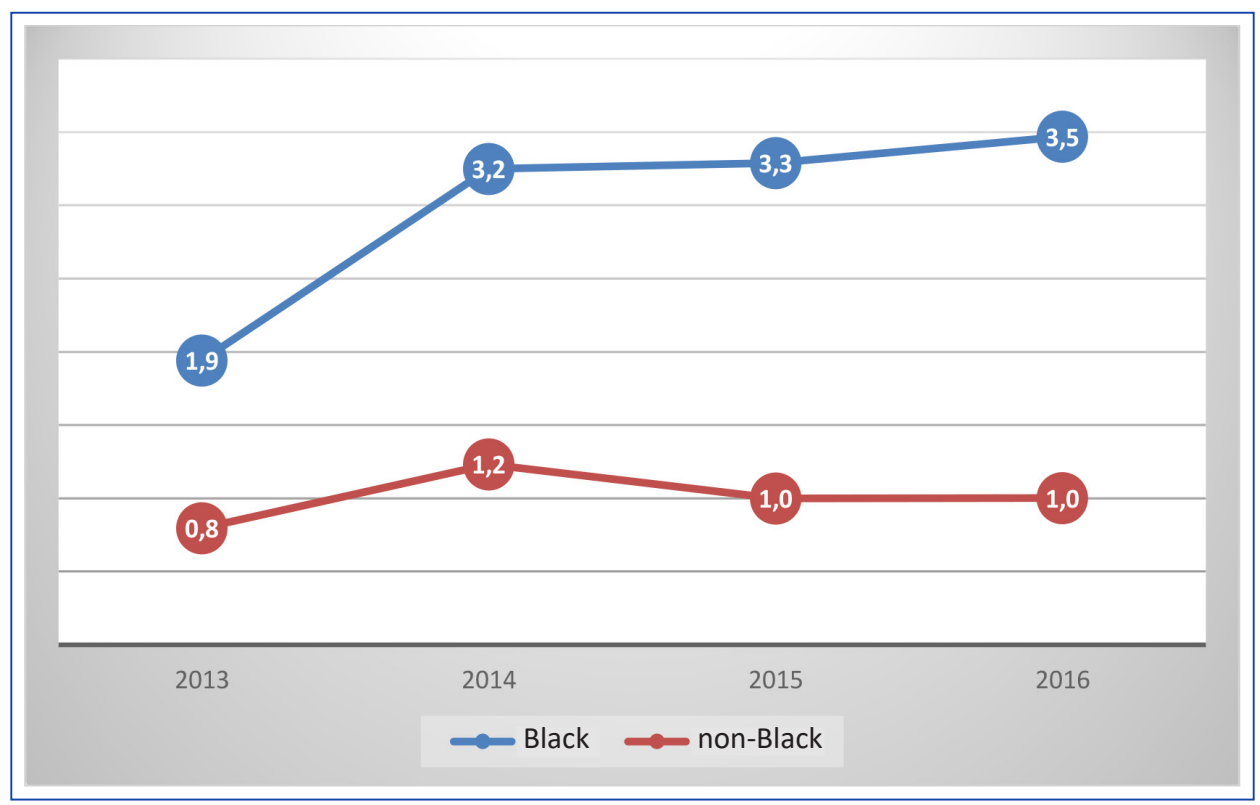

Source: Elaborated by the authors based on CAP / SSP data.

In search for answers to this question, Cano (2014) tests the existence of racial bias in the use of force by police officers in the states of Rio de Janeiro and São Paulo. The study showed a large racial disparity among police interventions victims compared to the general population, but the precariousness of the available data did not allow us to assess whether it is necessarily the result of bias in police actions. However, in the case of Rio de Janeiro, from where the most complete and consistent database the study had access to, the author confirmed the hypothesis of racial bias in the use of lethal force (CANO, 2014).

A work produced by Sinhoretto, Batitucci, Mota et al. (2014) also points to the overrepresentation of African descent people killed by police intervention in São Paulo, Rio de Janeiro, Federal District and Minas Gerais. The study, developed by request of the Ministry of Justice, showed the disproportion between white and African descent victims of police intervention resulting in death, which would be the result of a racial filtering in police intervention. This selectivity in police actions is understood as a byproduct in the field of public security of racialization in social relations in Brazil, producing institutional racism.

Schlittler (2016) suggests that the role played by the military police in controlling crime since the 1970's and the demands for more security at any cost have produced racial inequality. Supported by a militarized policing model, whose police suspicion is based on a construction of their own outlaw stereotype, the PM would be privileging the approach of young African descent by identifying in them the criminal element. According to the author, the elements that inform the suspicion are institutional in its nature and the result of practical experience, in which training is used to identify the criminal subject. From this perspective, what is at stake is not the personal racist conceptions a police officer might have, but rather a sort of institutionalized racism that is part of the organization itself.

Hubert G. Locke (apud GELLER, 1996) states that while the number of African descent injured, killed or pressed charges against police actions is disproportionately represented in the US case, claim that there is racial bias in police action is inaccurate as these results would vary according to situational perspectives of these interactions, according to police organizational structures, and to other individual characteristics of the civilians and police officers involved. Fryer Junior (2016) directs his conclusion to the same perspective by stating that while African descent and Hispanic people are about $50 \%$ more likely to be victims of police violence in non-killing approaches, it would not be possible to extend the conclusion to cases of lethal violence. 
Finally, in relation to the victims' age, Graph 6 shows that those killed in police actions are considerably younger than the murder victims in the state of São Paulo. Cano's (1997) study on Rio de Janeiro in the 1990's showed that most victims were aged 20 to 24 years. In São Paulo, 20 years later, the data indicate that the majority of victims are concentrated in the range between $15-19$ years old.

\section{Graph 6}

\section{Percentage of homicide and DRFPI victims by age group}

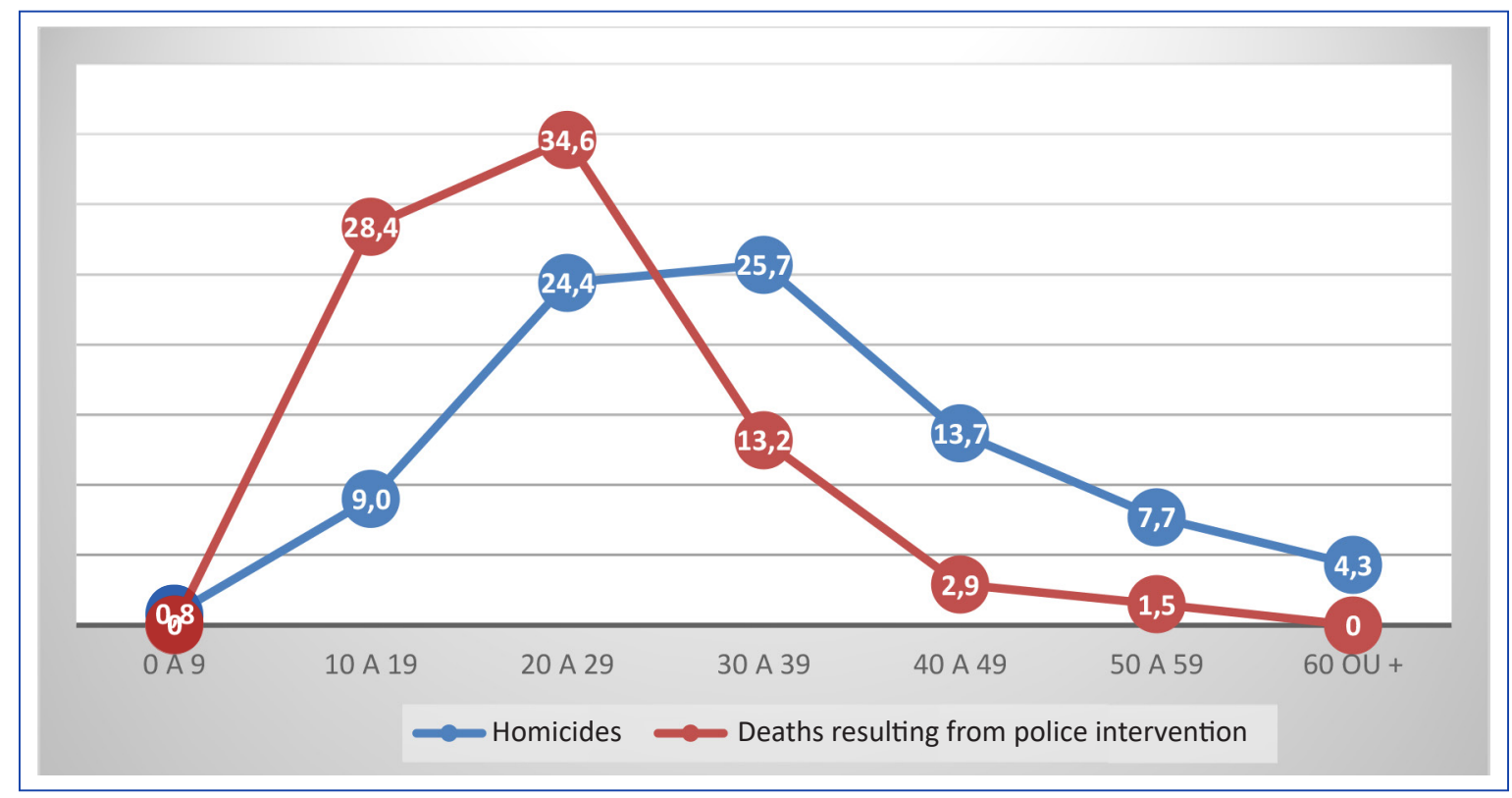

Source: Elaborated by the authors based on CAP / SSP data.

\section{CONCLUSION}

A significant part of the literature has indicated that the explanation for police lethality levels might be precisely in the profile of victims, which would be the result of the state agents' selectivity or the institutional racism present in corporations (BRUNSON and MILLER, 2006; CANO, 2014; KLINGER 1997; SCHLITTLER, 2016; SINHORETTO, BATITUCCI, MOTA et al., 2014). In addition, other researchers also indicate that because the victims are low-income people living in peripheral territories, it would most probably not cause public commotion, encouraging police officers to adopt as standard procedure the use of considerably more violent approaches and more intense use of force in these territories.

The crux of the matter is that the data indicate an overrepresentation of African descent and non-white people and also youngsters as victims of police lethality, even when compared to murder victims, a trend that has grown despite the reduction of murders in the state. If, from a normative point of view, the use of police force must comply with the criteria of proportionality, moderation and legality, being used only when there is imminent risk of death to police officers or third parties, thereby it does not seem logical that the violent used by the police force increases despite the reduction of the murder rates in the territory.

One element that has little been discussed by the specialized literature and that seems to be crucial in understanding the numbers presented here concerns the police officer's discretion during police interventions while patrolling the street. It is the street-level bureaucrat who actually implements the state politics on a daily basis and regulating it is extremely challenging to any public policy (SABATIER, 1986). However, when we talk about a state agent who has the power to decide on a citizen's life or death, it becomes even more complex.

It is up to the street-level professional to decide on the type and intensity of police action to best suited each situation, and given its discretionary and coercive nature, the Government and its instruments should establish, delimit and monitor the limits on the use of force of police mandate; after all, institutional action is manifested in the way its members act (BAYLEY, 2006). 
This variable is crucial not only to understand the pattern in the use of force, but also to think of appropriate responses to cases of abuse and illegality. In this case, the Public Prosecution Service and the Police Ombudsman Office, when effective, may constitute important external control mechanisms for police activity; however, they tend to be not as effective as they should.

In general police internal control mechanisms are more efficient because internal regulation has access to a larger volume of information compared to external actors, allowing a more complete and faster approach. Internal control mechanisms for police corporations may also cover a larger number of cases, not limited to those of greater repercussion, and may use formal and informal means to ensure execution, more over the police force is more likely to obey a law enforcement regulation than to behave in a certain way due to external regulation threats (BAYLEY, 2006; BUENO, 2014).

Another factor to consider is that usually external control mechanisms are perceived with suspicion by the police, who understand it as a punitive mechanism and not as conduct regulation. As consequence, the spread of external control agencies threatens organizational autonomy and police hide information and errors (BAYLEY, 2006). In an attempt to maintain ties with low-ranking professionals, officers tend to cover up their subordinates misconducts, further weakening their ability to selfregulate. Consequently, the institution has less control and therefore infringements occur more frequently; the population loses confidence in the police; and external control mechanisms become even more necessary. This happens because, although not always the most efficient, external controls are at times the only available mechanisms (BUENO, 2014).

The data presented here and the its historical evolution show that São Paulo police force have been using excessive lethal force according to the logic that indicates a pattern of selectivity that disproportionately victimizes African descent and nonwhite people, adolescents and youngsters. This tendency was intensified between 2013 and 2016 with the increase in police lethality, despite the reduction in the main violence indicator in a territory, which is murder. Understanding these actions and differentiating those in which there was legitimate use of force from the abusive and violent cases necessarily depends on an in-depth analysis of each case, which will only be effective with the active involvement of the "corregedorias" that are the internal control mechanisms responsible for analyzing, investigating, solving and/or forwarding reports of crimes and administrative offenses committed by military police force and agents, the main internal control mechanism of corporations.

The challenge is to ensure active internal control mechanisms and that those are held accountable an present before the population in which they operate the results of internal investigations, generating public reports of analyzed case results, referrals given to cases, and strengthening transparency in police institutions. Therefore, the pathway to follow would be to strengthen the accountability agenda, in particular those dedicated to transforming the huge amount of data produced by the criminal justice and public security institutions into monitoring indicators and more robust evaluation (LIMA, 2018) that could shed light on the dynamics and characteristics of the deaths resulting from police intervention in the country. 


\section{REFERENCES}

BAYLEY, D. H. Police for the future. New York: Oxford Univeristy Press, 1994.

BAYLEY, D. H. Padrões de Policiamento. São Paulo: Edusp, 2006.

BIDERMAN, C., DE MELLO, J.; SCHNEIDER, A. Dry Law and Homicides: Evidence from the São Paulo Metropolitan Area. Departamento de Economia, PUC-Rio: Texto para Discussão n. 518, 2006.

BITTNER, E. Aspectos do trabalho policial. São Paulo: Edusp, 2003.

BRASIL. Portaria Interministerial SDH/MJ no 4.226, de 31 de dezembro de 2010, que estabelece diretrizes sobre o uso da força pelos agentes de segurança pública. Diário Oficial da União, Jan. 03, 2011. n. 1, Seção 1, p. 27.

BRETAS, M. L.; PONCIONI, P. A cultura policial e o policial civil carioca. In: PANDOLFI, D. C. et al. (Org.). Cidadania, justiça e violência. Rio Janeiro: Editora Getúlio Vargas, 1999. p. 149-163.

BRUNSON, R. K.; MILLER, J. Young Black Men and Urban Policing in the United States. British Journal of Criminology, v. 46, p. 613-40, 2006.

BUENO, S. Bandido bom é bandido morto: a opção ideológicoinstitucional da política de segurança pública na manutenção de padrões de atuação violentos da polícia militar paulista. 2014. 145 f. Thesis (Master of Public Administration and Government) - Escola de Administração de Empresas de São Paulo, Fundação Getulio Vargas, São Paulo, 2014.

CANO, I. Letalidade da ação policial no Rio de Janeiro. Rio de Janeiro: ISER, 1997.

CANO, I. Viés racial no uso da força letal pela polícia no Brasil. MPMG Jurídico, v. 1, p. 17-25, 2014.

CHEVIGNY, P. Edge of the knife: police violence in the Americas. New York: New York Press, 1995.

COSTA, A. T. M. Entre a lei e a ordem: violência e reforma nas polícias do Rio de Janeiro e Nova York. São Paulo: Editora FGV, 2004.

DIAS, C. N. Da guerra à gestão: a trajetória do Primeiro Comando da Capital (PCC) nas prisões de São Paulo. Revista Percurso: Sociedade, Natureza e Cultura, Ano VIII, v. 2, n. 10, p. 79-96, 2009.

FELTRAN, Gabriel de Santis. Crime e castigo na cidade: os repertórios da justiça e a questão do homicídio nas periferias de São Paulo. Cad. CRH, Salvador, v. 23, n. 58, p. 59-73, Apr. 2010. Available at: <http://dx.doi.org/10.1590/S0103-49792010000100005>. Accessed on: July 28, 2019.

FELTRAN, G. S. Governo que produz crime, crime que produz governo: o dispositivo de gestão do homicídio em São Paulo (1992-2011). Revista Brasileira de Segurança Pública, v. 6, n. 2, 2012.

FERNANDES, H. R. Política e Segurança: Força Pública do Estado de São Paulo - fundamentos histórico-sociais. São Paulo: Editora AlfaOmega, 1973.

FERREIRA, S. P.; LIMA, R. S.; BESSA, V. Criminalidade Violenta e Homicídios em São Paulo: fatores explicativos e movimentos recentes. In: SILVA FILHO, T. J.; DURANTE, M. O. (Eds.). Homicídios: políticas de prevenção e controle. Brasília, DF: Ministério da Justiça; Porto Alegre: UFRGS, 2009. p. 11-20. (Coleção Segurança com Cidadania.
Vol. 3). p. 11-20. Available at: <https://goo.gl/6amFBT>. Accessed on: Nov. 23, 2017.

FYFE, J. Blind Justice: Police Shootings in Memphis. Journal of Criminal Law and Criminology, v. 73, n. 2, p. 707-22, 1982.

FRYER JUNIOR, R. G. An empirical analysis of racial differences in police use of force. Cambridge: National Bureau of Economic Research, 2016. (Working Paper, n. 22399) Available at: < https:// doi.org/10.3386/w22399>. Accessed on: July 28, 2019.

FÓRUM BRASILEIRO DE SEGURANÇA PÚBLICA. Anuário Brasileiro de Segurança Pública, ano 9, 2015.

GELLER, W.; TOCH, H. (Ed.). Police violence: understanding and controlling police abuse of force. New Haven: Yale University Press, 1996.

INTITUTO SOU DA PAZ. Regulações sobre o Uso da Força pelas Polícias Militares dos estados de São Paulo e Pernambuco. In: SECRETARIA NACIONAL DE SEGURANÇA PÚBLICA. Direitos humanos. Brasília: Ministério da Justiça; Secretaria Nacional de Segurança Pública, 2013. (Coleção Pensando a Segurança Pública, v. 2).

JUSTUS. M.; KAHN, T.; CERQUEIRA, D. O “Mistério de São Paulo" e o Papel do PCC na redução de homicídios nos anos 2000. Campinas: UNICAMP, 2016.

KAHN, T.; ZANETIC, A. O papel dos municípios na segurança pública. Relatório final: concursos nacionais em pesquisas aplicadas em justiça criminal e segurança pública. Brasília: Secretaria Nacional de Segurança Pública, 2005.

KANIA, R.; MACKEY, W. Police violence as a function of community characteristics, Criminology, v. 15, n. 1, p. 27-48, 1977

KAPPELER, V. E.; SLUDER, R. D; ALPERT, G. P. Forces of deviance: understanding the dark side of policing. Long Grove: Waveland Press Inc., 1994.

KLINGER, D. A. Negotiating Order in Patrol Work: An Ecological Theory of Police Response to Deviance. Criminology, v. 35, n. 2, p. 277-306, 1997.

LESTER, D. Officer attitudes toward police use of force. In: GELLER, W. A.; $\mathrm{TOCH}, \mathrm{H}$. (Ed.). Police violence - understanding and controlling police abuse of force. New Haven: Yale University Press, 1996. p. 180-190.

LIMA, R. S. Criminalité violente et homicides à São Paulo. L'Ordinaire des Amériques, v. 216, p. 1-10, 2014. Available at: <https://journals. openedition.org/orda/1138>. Accessed on: July 28, 2019.

LIMA, R.S. Violence and Public Safety as a Democratic Simulacrum in Brazil. International Journal of Criminology and Sociology, v. 7, p. 159-172, 2018.

LIPSKY, M. Street Level Bureaucracy: Dilemmas of the Individual in Public Services. New York, NY: The Russel Sage Foundation, 2010.

LOCHE, A. A letalidade de ação policial: parâmetros para análise. TOMO - Revista do Núcleo de Pós-Graduação e Pesquisa em Ciências Sociais, São Cristóvão, n. 17, July/Dec., 2010.

MANSO, B. P. Crescimento e queda dos homicídios em SP entre os anos de 1960 e 2010 - Uma análise dos mecanismos da escolha homicida e das carreiras no crime. 2012. Thesis (Doctor Degree in 
Political Science) - Programa de Pós-Graduação em Ciência Política, Universidade de São Paulo, São Paulo, 2012.

MELLO, J. M. P.; SCHENEIDER, A. Mudança demográfica e a dinâmica dos homicídios no Estado de São Paulo. São Paulo Perspectiva, v. 21, n. 1, p. 19-30, 2007.

MENA, F. Um a cada 3 brasileiros tem medo de violência e da polícia, aponta pesquisa. Folha de São Paulo, São Paulo, July 03, 2017. Available at: <https://www1.folha.uol.com.br/cotidiano/2017/07/18979051-a-cada-3-brasileiros-tem-medo-de-violencia-e-da-policia-apontapesquisa.shtml>. Accessed on: July 28, 2019.

MISSE, M. et al. Quanto a polícia mata: homicídios por "autos de resistência" no Rio de Janeiro (2001-2011). 1. ed. v. 1. Rio de Janeiro: Booklink, 2013. p. 193.

MONJARDET, D. O que faz a polícia: Sociologia da Força Pública. Tradução: Mary Amazonas Leite de Barros. São Paulo: Edusp, 2002.

MUNIZ, J.; PROENÇA JÚNIOR, D.; DINIZ, E. Uso de força e ostensividade na ação policial. Conjuntura Política: Boletim de Análise, n. 6, p. 22-26, Apr. 1999.

NERY, M. B. Crime e violência no cenário paulistano: o movimento e as condicionantes dos homicídios dolosos sob um recorte espaçotemporal. 2016. 207 f. São Paulo, 2016. Thesis (Doctor Degree in Sociology) - Faculdade de Filosofia, Letras e Ciências Humanas da Universidade de São Paulo, São Paulo, 2016.
PERES, M. F. T. et al. Queda dos homicídios em São Paulo, Brasil: uma análise descritiva. Revista Panamericana de Salud Pública, v. 29, p. 17-26, 2011.

SABATIER, P. A. What can we learn from implementation research? In: KAUFMAN, F. X.; MAJONE, G.; OSTROM, V. (Orgs.). Guidance, control and evaluation in the public sector: the Bielefeld interdisciplinary project. Berlin: De Gruyter, 1986. p. 313-325.

SINHORETTO, J. et al. A filtragem racial na seleção policial de suspeitos: segurança pública e relações raciais. In: SECRETARIA NACIONAL DE SEGURANÇA PÚBLICA. Segurança pública e direitos humanos: temas transversais. Brasília: Ministério da Justiça; Secretaria Nacional de Segurança Pública, 2014. (Coleção Pensando a Segurança Pública, v. 5).

SCHLITTLER, M. C. "Matar muito, prender mal”: A produção da desigualdade racial como efeito do policiamento ostensivo militarizado em SP. 2016. Thesis (Doctor Degree in Sociology) - Programa de Pós-Graduação em Sociologia, Universidade Federal de São Carlos, São Paulo, 2016.

SKOLNICK, J.; FYFE, J. Above the law: police and the excessive use of force. New York: Free Press, 1993.

WILLIS, G. A. N. The killing consensus: homicide detectives, police that kill and organized crime in São Paulo, Brazil. 2013. Thesis (Doctor Degree in Urban and Regional Studies) - Massachusetts Institute of Technology, Dept. of Urban Studies and Planning, 2013.

Samira Bueno

ORCID: https://orcid.org/0000-0002-5784-148X

PhD in Public Administration and Government from the Getulio Vargas Foundation School of Business Administration (FGV EAESP); Executive Director of the Brazilian Public Safety Forum, São Paulo- SP, Brazil. E-mail: sbueno@forumseguranca.org.br

Renato Sérgio de Lima

ORCID: https://orcid.org/0000-0002-0935-699X

PhD in Sociology from the University of São Paulo (USP); CEO of the Brazilian Public Security Forum; Professor of the Department of Public Management at the Getulio Vargas Foundation School of Business Administration (FGV EAESP), São Paulo- SP, Brazil. E-mail: Renato.lima@fgv.br

Marco Antônio Carvalho Teixeira

ORCID: https://orcid.org/0000-0003-3298-8183

PhD in Political Science from the Pontifical Catholic University of São Paulo (PUC-SP); Professor of the Department of Public Management at the Getulio Vargas Foundation School of Business Administration (FGV EAESP), São Paulo- SP, Brazil. E-mail: marco.teixeira@fgv.br 